\title{
ON THE QUESTION OF THE COMPETENCE OF FORENSIC EXPERTS DURING CERTAIN EXAMINATIONS?
}

\author{
A.E. Dorofyeyev, O. V. Deryugina, V. L. Kolesnikov
}

Summary. The article explains the concept of the competence of forensic experts in answering questions about the law enforcement agencies, which are put to the expert, but are beyond the scope of forensic medicine. Held their legal and forensic justification. The article also includes recommendations for the compilation of answers to questions on the main three areas encountered in practice experts.

Key vords: forensic medicine.

\section{НА ВСЕ ЛИ ВОПРОСЫ СУДЕБНО-МЕДИЦИНСКИЙ ЭКСПЕРТ МОЖЕТ ДАВАТЬ КОМПЕТЕНТНЫЕ ОТВЕТЫ СЛЕДСТВЕННО-СУДЕБНЫМ ОРГАНАМ?}

\author{
А. Е. Дорофеев, О. В. Дерюгина, В. Л. Колесников
}

Резюме. Следует обратить внимание судебно-медицинских экспертов на проведение четкого дифференцирования пределов компетенции в экспертной практике и на недопустимость нарушения действующих юридических и медицинских документов (а это именно нарушение). Изложенные в статье подходы позволяют избежать указанные нарушения УПК Украины и Приказа №6 МО3 Украины.

Ключевые слова: судебно-медицинская экспертиза.

\section{ЕКСПРЕС-МЕТОД ОЧИЩЕННЯ КІСТОК ВІД М'ЯКИХ ТКАНИН 3 МЕТОЮ ДОСЛІДЖЕННЯ ХАРАКТЕРУ КРАЇВ ПЕРЕЛОМІВ}

\author{
СКолесник О. О. ${ }^{1}$, Фащенко А. В. ${ }^{2}$ \\ Вінницьке обласне бюро судово-медичної експертизи ${ }^{1}$ \\ Запорізьке обласне бюро судово-медичної експертизи ${ }^{2}$
}

Резюме. Робота присвячена експрес-методу очищення кісток від м'яких тканин з метою дослідження характеру країв переломів, тривалість якого складає всього 20 хвилин. Для мацерації запропоновано використовувати хімічну сполуку - розчин їдкого калію (гідроокису калію, КОН), що є альтернативою мацерації кісток у проточній теплій воді, витримці їх в термостаті на протязі декількох діб та механічній мацерації. Запропонована методика потребує мінімум часу та зусиль експерта, $€$ простою, зручною та економічно вигідною.

Ключові слова: кістки, перелом, мацерація, очищення від м’яких тканин, розчин їдкого калію, КОН, хімічна мацерація.

ВСТУП. Травматизм є одним із важливих об’єктів дослідження в судовій медицині. Особливої уваги при цьому заслуговує визначення механизму та характеру утворення переломів кісток скелету людини, що дозволяє отримати інформацію щодо особливостей травми, кількості, послідовності утворення пошкоджень та допомагає смоделювати умови, в яких пошкодження утворилися.

Однак дослідження переважної кількості переломів кісток представляє труднощі, причому як в ході проведення розтину трупів, так і при детальному вивченні об'єктів в умовах відділень судово-медичної криміналістики. Ці труднощі перед усім зумовлені тим, що зв'язковий апарат та скелетні м'язи важко відділяються від кісток, потребують від експерта проведення тривалої та ретельної механічної (ручної) мацерации.

Тривалий час [1] для полегшення процедури очищення кісток від м'яких тканин використовувалася мацерація їх у проточній теплій воді на протязі 3 - 5 діб або в термостаті при температурі 30 градусів на протязі 1 - 2 діб (згідо методичного листа № 1341 від 13.06.1986 р. к.м.н. С.С. Абрамова - завідувача фізикотехнічним відділенням Бюро Головної судово-медичної експертизи РСФСР «Об изъятии и подготовке остеологического материала к исследованию в отделах экспертизы трупов и физико-технических отделениях»). Після такої мацерації залишки м'яких тканин відділялися від кісток за допомогою струменю води та волосяної щітки або деревяної палички, висушувалися при кімнатній температурі та знежирювалися в хлороформі або спиртовоефірній сумішші (1:1). Однак, приготовуння кісткових препаратів запропонованими методами займає ще більше часу ніж механічна мацерація кісток. 
Мета дослідження. Пропонуємо вашій увазі експрес-метод очищення кісток від м’яких тканин за допомогою хімічної сполуки - розчину їдкого калію (гідроокису калію). Тривалість обробки кісток за даним методом складає всього 20 хвилин.

Матеріал і методи дослідження. Їдкий калій (гідроокис калію, КОН, каустичний поташ, гідрат окису калію, гидроокис калію) за своєю хімічою структурою відноситься до лугів (сильних основ). Він має унікальну властивість в десятки разів пришвидшувати розчинення органічних сполук. Його активно використовують в мисловствознавстві для виготовлення черепів тварин, які мають музейно-коллекційну, експозиційну та трофейну цінность [2]; на виробництві для очищення каналізаційних труб; в умовах промислової мийки виробів із нержавіючої сталі (розчином їдкого калію очищують від жирів та олій м'ясорубки, емності для зберігання м'ясных продуктів, тощо). Їдкий калій доступний у використанні, дешево коштує, не потребує ліцензії на придбання і має тривалий термін зберігання.

Візуально речовина має вигляд гігроскопічних гранул білого кольору, при взаємодії яких 3 водою виділяється велика кількість тепла. Водний розчин їдкого калію при взаємодії з органічними сполуками швидко проникає в тканини, викликає гідроліз білка та коллікваційний (вологий) некроз, завдяки чому м'які тканини повністю розчиняються або перетворюються на слизоподібну масу, яка з легкістю відділється від кісток.

Шляхом проведення неодноразових експериментальних досліджень була встановлена оптимальна концентрація розчину їдкого калію та тривалість занурення у нього фрагментів кісток із м’якими тканинами. При оптимальній концентрації м'які тканини швидко розчиняються, а губчаста та компактна речовина кістки в ділянці країв переломів не пошкоджується, тобто характер країв переломів не змінюється.

РЕЗУЛЬТАТИ ДОСЛІДЖЕННЯ ТА ЇХ ОБГОВОРЕННЯ. Методика підходиТь для обробки любих кісток скелету людии (трубчасті, губчасті, пласкі) та фрагментів кісток із переломами.

Пропонуємо використовувати в роботі наступний алгоритм:

1. Вилучити з трупа фрагмент кістки з переломом, необхідний для детального дослідження (рис. 1). Ретельне очищення його від м'яких тканин не потрібне!

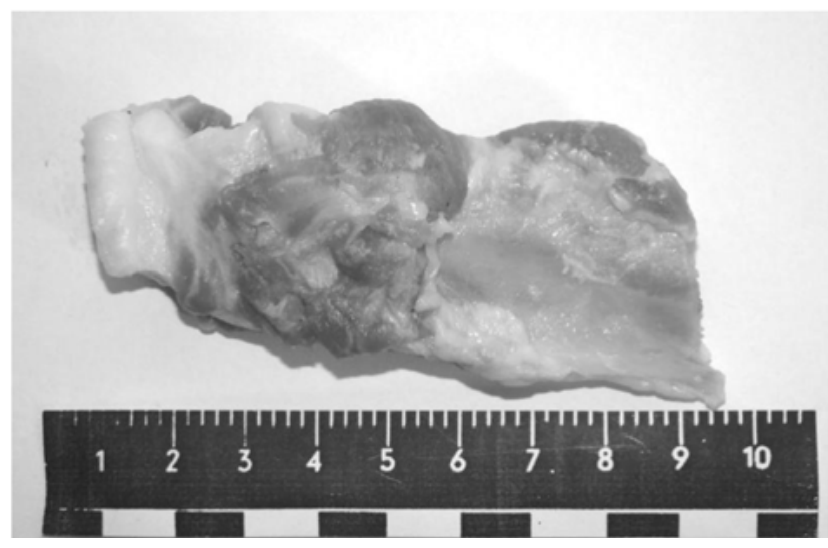

Рис. 1. Вигляд фрагмента ребра із м'якими тканинами

2. Зважити необхідну кількість гранул їдкого калію для приготування водного розчину їдкого калію. Оптимальною концентрацією розчину КОН є 5\% водний розчин даної речовини (із розрахунку 5 г гранул КОН на 100 мл води).

3. Висипати гранули в ємність для мацерації (емалірований медичний лоток, відро, колбу із термоскла, тощо).

4. Закіп'ятити необхідну кількість води.

5. Гарячою водою $\left(90-100{ }^{\circ} \mathrm{C}\right)$ залити гранули їдкого калію. Увага! При контакті речовини із водою виникає бурхлива реакція, що супроводжується активним піноутворенням. Не наближати обличчя до ємностю 3 рідиною! При роботі обов'язково вдягати гумові рукавички та халат.

6. Занурити в гарячий розчин КОН фрагмент кістки із м’якими тканинами так, щоб рідина повністю приховувала фрагмент.

7. Середня витримка кістки в розчині складає 20 хвилин. Необхідно постйно слідкувати за швидікістю процесу розчинення м'яких тканин. Якщо на поверхні розчину з'являється плівка жиру, ії треба знімати (виникає при обробці великих фрагментів трубчастих кісток). У разі необхідності, фрагменти кісток можна вилучити 3 розчину раніше 20-хвилинного терміну (рис. 2). При обробці мініатюрних кісток (під’язикова кістка) зазвичай достатньо 7 - 10 хвилин обробки в розчині їдкого калію. 


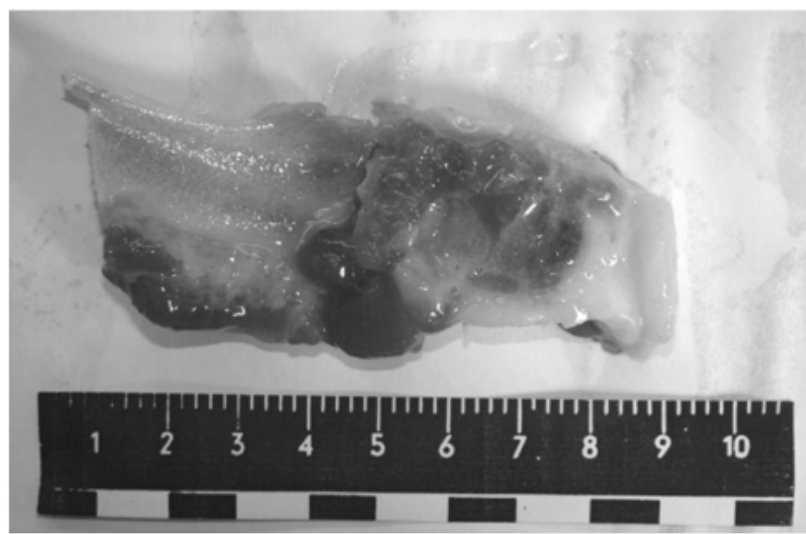

Рис. 2. Вигляд фрагмента ребра із напіврозчиненими залишками м'яких тканин

8. Змити залишки м’яких тканин з поверхні кістки під проточною водою, використовуючи щітку та висушити готовий препарат.

Гарячий розчин їдкого калію не тільки полегшує відділення м'яких тканин від кісток, він також знежирює і дещо відбілює їх (рис. 3). Допускається заміна розчину їдкого калію на розчин їдкого натрію - $\mathrm{NaOH}$ (каустична сода), який також є сильним лугом.

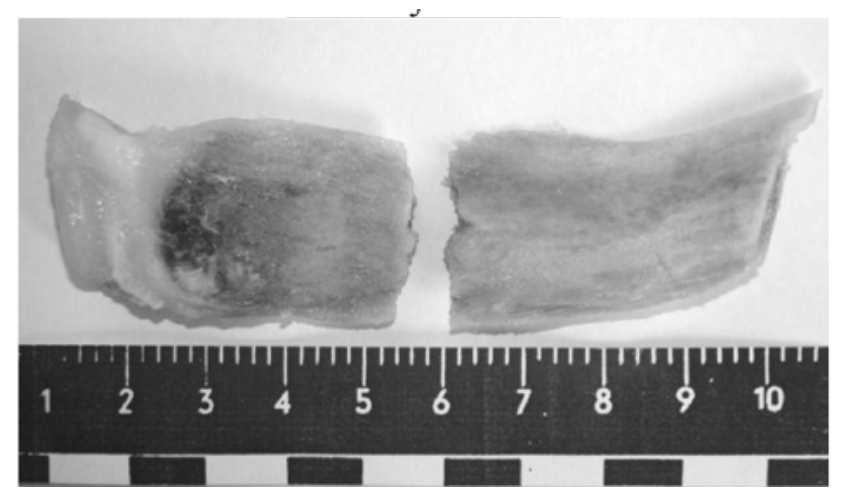

Рис. 3. Вигляд очищеного фрагмента ребра

Увага! Не варто використовувати в роботі занадто концентровані розчини лугів - вони здатні згладжувати характер країв переломів, змінюючи їх істинну картину. Запропонований метод підходить лише для обробки кісток і не підходить для обробки хрящів (суглобові хрящі, щитоподібний хрящ, тощо). Це зумовлено особливістю структури хряща, вона як і м’язи швидко піддається гідролізу, некрозу та може розчинятися (повністю або частково) в розчині їдкого калію.

\section{ВИСНОВКИ}

Запропонована нами методика очищення кісток від м'яких тканин за допомогою хімічної сполуки - гарячого розчину їдкого калію є швидкісною (триває не більше 20 хвилин), простою, зручною, економічно вигідною та доступною у використанні як в умовах моргу, так і у відділеннях судово-медичної криміналістики. Метод $є$ альтернативою тривалій механічній мацерації, мацерації кісток у проточній теплій воді та витримці їх в термостаті на протязі декількох діб.

\section{Література}

1. Об изъятии и подготовке остеологического материала к исследованию в отделах экспертизы трупов и физико-технических отделениях: методическое письмо №1341 / С.С. Абрамов - М., 1986.

2. Обработка охотничьих трофеев. Охота и охотничье хозяйство/ М. Заславский // 1980 г. - № 1. 


\title{
ЭКСПРЕСС-МЕТОД ОЧИСТКИ КОСТЕЙ ОТ МЯГКИХ ТКАНЕЙ С ЦЕЛЬЮ ИССЛЕДОВАНИЯ ХАРАКТЕРА КРАЕВ ПЕРЕЛОМОВ
}

\author{
Колесник О. А., Фащенко А. В.
}

Резюме. Работа посвящена экспресс-методу очистки костей от мягких тканей с целью исследования характера краев переломов, длительность которого составляет всего 20 минут. Для мацерации предложено использовать химическое соединение - раствор едкого калия (гидроокиси калия, КОН), что является альтернативой мацерации костей в проточной теплой воде, выдержке их в термостате в течение нескольких суток и механической мацерации. Предложенная методика требует минимум времени и усилий эксперта, является простой, удобной и экономически выгодной.

Ключевые слова: кости, перелом, мацерация, очистка от мягких тканей, раствор едкого калия, КОН, химическая мацерация.

\section{EXPRESS METHOD OF BONES CLEANING FROM SOFT TISSUES AIMED TO EXAMINE TYPE OF FRACTURE EDGES}

\author{
Kolesnik O. A., Fashchenko A. V.
}

Summary. The paper is devoted to the express method of bones cleaning from soft tissues aimed to examine type of fracture edges; its duration is only 20 minutes. For maceration is proposed to use chemical compound - solution of potassium hydroxide (potassium hydrate, $\mathrm{KOH}$ ), that is the alternative of bones maceration in running warm water, their holding in thermostat during several days and mechanical maceration. Suggested method requires minimum of time and efforts of specialist, is simple, convenient and costefficient.

Key words: bones, fracture, maceration, cleaning from soft tissues, solution of potassium hydroxide, $\mathrm{KOH}$, chemical maceration.

УДК $615.07-615.099 / 340.67$

\section{ВИКОРИСТАННЯ МЕТОДУ ТВЕРДОФАЗНОЇ ЕКСТРАКЦЇ̈ ПРИ ДІАГНОСТИЦІ СМЕРТЕЛЬНИХ ОТРУСНЬ ПЕСТИЦИДАМИ МЕТОДОМ ГХ-МС}

\author{
СШевчук М. М. ${ }^{1,2}$, Тарнавська Я. Г. ${ }^{1}$, Ковалишин В. М. ${ }^{1}$, \\ Галькевич І. Й. ${ }^{2}$
}

Львівське обласне бюро судово-медичної експертизи ${ }^{1}$

Львівський національний медичний університет ім. Данила Галицького 2

\begin{abstract}
Резюме: В роботі показано вплив підготовки проби на результат визначення карбофурану методом ГХ-МС в біологічному матеріалі при смертельних отруєннях. Показано, що застосування методу твердофазної екстракції дозволяє підвищити чутливість визначень до 15 разів, порівнюючи із очисткою проб в тонкому шарі сорбенту.

Ключові слова: карбофуран, ГХ-МС, підготовка проби, твердофазна екстракція.
\end{abstract}

ВСТУП. В практичній роботі токсикологічних відділень бюро судово-медичної експертизи для підтвердження наявності отрути в трупному матеріалі застосовуються хроматографічні методи аналізу, серед яких вагоме місце займає газова хроматографія (ГХ) та високоефективна рідинна хроматографія (BЕРХ). Оснащення приладів мас-детекторами дозволяє 3 вищою достовірністю виявляти токсичні компоненти та значно прискорювати час виконання судово-хімічної експертизи. Сучасні хроматографи оснащені програмним забезпеченням та бібліотекою мас-спектрів, що спрощує проведення ідентифікації отруйних сполук і тому ГХ- МС та ВЕРХ-МС є одними із оптимальних методів виявлення та кількісного визначення різних речовин в біологічних об'єктах [4, 9].

По своїй суті судово-токсикологічне дослідження включає етапи ізолювання, очистки проби, концентрування та підтвердження наявності отруйної сполуки хімічними та фізико-хімічними методами аналізу. Проте при застосуванні ГХ-МС чи ВЕРХ-МС експерти зустрічаються з проблемами, які зумовлені впливом компонентів біологічної проби на мас-спектрометричне визначення досліджуваних речовин. При настоюванні трупних органів з ізолюючими розчинами у витяжки потрапляють білки, пігменти, ферменти, жирові компоненти, жовчні кислоти та інші супутні речовини. Після концентрування отруйних сполук рідинною екстракцією супутні домішки потрапляють в органічні екстракти і впливають на результат визначення [3]. 